\title{
Pengaruh Pendekatan Metakognisi Terhadap Kemampuan Pemecahan Masalah Matematika Mahasiswa Mesin Dan Peralatan Pertanian Politeknik Gorontalo
}

\author{
Devitta Purnamasary Mohiddin \\ Program Studi Mesin dan Peralatan Pertanian \\ Politeknik Gorontalo \\ devitta.pm@poligon.ac.id
}

\begin{abstract}
Pendekatan metakognitif dalam pembelajaran matematika dapat dilaksanakan dengan berbagai cara, selama yang menjadi inti pembelajarannya adalah untuk mengevaluasi metakognisi siswa melalui pemberianpemberian pertanyaan-pertanyaan metakognitif. Salah satu cara yang diusulkan oleh penulis adalah dengan menggunakan kartu metakognisi, yang berisi pertanyaanpertanyaan metakognitif yang dapat disesuaikan dan disusun berdasarkan topik atau materi yang sedang dipelajari di kelas. Penelitian ini bertujuan untuk mengetahui : (1)Menganalisis dan menguji peningkatan pemahaman konsep mahasiswa melalui pendekatan metakognisi, (2)Menganalisis dan menguji peningkatan pemahaman konsep mahasiswa dalam meningkatkan kemampuan pemecahan masalah integral melalui pendekatan metakognisi.
\end{abstract}

Kata kunci : Pendekatan metakognisi, Pemecahan masalah integral

\section{PENDAHULUAN}

Matematika dengan hakikatnya sebagai suatu kegiatan manusia melalui proses yang aktif, dinamis, dan generatif, serta sebagai pengetahuan yang terstruktur, mengembangkan sikap berpikir kritis, objektif, dan terbuka menjadi sangat penting untuk dimiliki peserta didik dalam menghadapi perkembangan IPTEK yang terus berkembang. Dengan demikian diperlukan penguasaan matematika yang kuat sejak dini, sehingga matematika perlu diberikan kepada semua peserta didik mulai dari sekolah dasar, hal ini untuk membekali peserta didik dengan kemampuan berpikir logis, analitis, sistematis, kritis, dan kreatif, serta kemampuan bekerjasama. Kompetensi tersebut diperlukan agar peserta didik dapat memiliki kemampuan memperoleh, mengelola, dan memanfaatkan informasi untuk bertahan hidup pada keadaan yang selalu berubah, tidak pasti, dan kompetitif (Depdiknas, 2006).

Rendahnya kualitas penguasaan materi Integral oleh mahasiswa, dimungkinkan terjadi karena mahasiswa kurang mendapatkan latihan dalam memecahkan masalah. NCTM menjelaskan bahwa problem solving dalam pendidikan matematika didefinisikan sebagai "problem solving means engaging in a task for which the solutions is not known in advance". Hal ini berarti bahwa masalah yang cocok bagi problem solving tidak harus soal cerita atau masalah dunia nyata. Sepanjang mahasiswa tidak tahu bagaimana memecahkan masalah, maka masalah tersebut dapat diklasifikasikan sebagai masalah problem solving bagi mahasiswa. Proses pemecahan masalah merupakan alat yang digunakan untuk mengubah dari keadaan yang ditemui menjadi keadaan yang diinginkan. Polya dalam Kurniawan mengembangkan empat langkah pemecahan masalah yaitu memahami masalah (understand problem), menyusun rencana pemecahan (make a plan), melaksanakan rencana pemecahan (carry out a plan), memeriksa kembali hasil pemecahan (look back at the completed solution). Kemampuan pemecahan masalah sebenarnya dapat dilatihkan oleh dosen kepada mahasiswa, namun hal ini masih jarang dilakukan oleh dosen. Kalaupun mahasiswa mendapatkan latihan pemecahan masalah, biasanya dosen yang bersangkutan tidak memberikan balikan terhadap hasil pekerjaan mahasiswa. Akibatnya, mahasiswa tidak pernah mengetahui kebenaran tugas yang dikerjakan. Mahasiswa selalu beranggapan bahwa apa yang dikerjakan telah "benar" karena dosen pengampu mata kuliah tidak pernah memberikan balikan terhap hasil pekerjaannya.

Metakognitif merupakan suatu bentuk kemampuan untuk melihat diri sendiri sehingga apa yang dia lakukan dapat terkontrol secara optimal. Pendekatan metakognitif menekankan pengembangan kesadaran peserta didik akan kemampuan dirinya tentang pemahaman konsep, pemahaman masalah, mengembangkan hubungan pengetahun baru dengan yang lalu, strategi penyelesaian, refleksi proses dan solusi yang mengajarkan (Nindiasari, 2013) : a. Bagaimana mengontrol aktifitas berpikir b. Berpikir tentang proses berpikir khususnya dalam memahami masalah, mempertimbangkan strategi penyelesaian masalah, melakukan refleksi pada proses dan solusi yang telah dilakukan. Oleh karena itu, pembelajaran metakognitif diharapkan dapat menjadi solusi dalam membangun kemampuan matematis siswa dalam proses berpikir dan proses pembelajarannya.

\section{TINJAUAN PUSTAKA}

2.1 Hakekat Pemecahan Masalah Matematika

Terdapat banyak interpretasi tentang pemecahan masalah dalam matematika. Di antaranya pendapat Polya 
(1985) yang banyak dirujuk pemerhati matematika. Polya mengartikan pemecahan masalah sebagai suatu usaha mencari jalan keluar dari suatu kesulitan guna mencapai suatu tujuan yang tidak begitu segera dapat dicapai. Sementara Sujono (1988) melukiskan masalah matematika sebagai tantangan bila pemecahannya memerlukan kreativitas, pengertian dan pemikiran yang asli atau imajinasi. Berdasarkan penjelasan Sujono tersebut maka sesuatu yang merupakan masalah bagi seseorang, mungkin tidak merupakan masalah bagi orang lain atau merupakan hal yang rutin saja.

Ruseffendi (1991b) mengemukakan bahwa suatu soal merupakan soal pemecahan masalah bagi seseorang bila ia memiliki pengetahuan dan kemampuan untuk menyelesaikannya, tetapi pada saat ia memperoleh soal itu ia belum tahu cara menyelesaikannya. Dalam kesempatan lain Ruseffendi (1991a) juga mengemukakan bahwa suatu persoalan itu merupakan masalah bagi seseorang jika: pertama, persoalan itu tidak dikenalnya. Kedua, peserta didik harus mampu menyelesaikannya, baik kesiapan mentalnya maupun pengetahuan siapnya; terlepas daripada apakah akhirnya ia sampai atau tidak kepada jawabannya. Ketiga, sesuatu itu merupakan pemecahan masalah baginya, bila ia ada niat untuk menyelesaikannya.

Lebih spesifik Sumarmo (1994) mengartikan pemecahan masalah sebagai kegiatan menyelesaikan soal cerita, menyelesaikan soal yang tidak rutin, mengaplikasikan matematika dalam kehidupan sehari-hari atau keadaan lain, dan membuktikan atau menciptakan atau menguji konjektur. Berdasarkan pengertian yang dikemukakan Sumarmo tersebut, dalam pemecahan masalah matematika tampak adanya kegiatan pengembangan daya matematika (mathematical power)terhadap peserta didik.

\subsection{Kajian Tentang Pendekatan Pembelajaran}

Pendekatan pembelajaran dapat diartikan sebagai titik tolak atau sudut pandang kita terhadap proses pembelajaran, yang merujuk pada pandangan tentang terjadinya suatu proses yang sifatnya masih sangat umum, di dalamnya mewadahi, menginsiprasi, menguatkan, dan melatari metode pembelajaran dengan cakupan teoretis tertentu. Dilihat dari pendekatannya, pembelajaran terdapat dua jenis pendekatan, yaitu: (1) pendekatan pembelajaran yang berorientasi atau berpusat pada peserta didik (student centered approach) dan (2) pendekatan pembelajaran yang berorientasi atau berpusat pada guru (teacher centered approach).

Pendekatan pembelajaran merupakan cara kerja mempunyai sistem untuk memudahkan pelaksanaan proses pembelajaran dan membelajarkan peserta didik guna membantu dalam mencapai tujuan yang telah ditetapkan.

Pendekatan dapat diartikan sebagai titik tolak atau sudut pandang kita terhadap proses pembelajaran. Pendekatan yang berpusat pada guru menurunkan strategi pembelajaran langsung (direct instruction), pembelajaran deduktif atau pembelajaran ekspositori. Sedangkan, pendekatan pembelajaran yang berpusat pada peserta didik menurunkan strategi pembelajaran discovery dan inkuiri serta strategi pembelajaran induktif (Sanjaya, 2008:127).

\subsection{Pendekatan Metakognisi}

Metakognisi adalah suatu kata tentang apa yang seseorang ketahui tentang dirinya sendiri sebagai individu dan bagaimana ia mengontrol dan menyesuaikan perilakunya. Terdapat banyak definisi yang berkaitan dengan metakognisi menurut para ahli. Weissinger (Nindiasari, 2013) mengemukakan, metakognisi merupakan kemampuan dalam memantau tingkat pemahaman dan menentukan kapan pemahaman ini tidak memadai, kemampuan refleksi diri dalam pengembangan kemampuan berpikir serta kebiasaan kecenderungan untuk menggunakannya.

Costa (2001) mengemukakan, metakognisi adalah kemampuan untuk merencanakan suatu stategi untuk menghasilkan informasi yang dibutuhkan dalam mencari solusi suatu masalah, menetapkan langkah-langkah strategi yang akan dilaksanakan, serta merefleksi dan mengevaluasi produktivitas kemampuan berpikirnya. Dengan kata lain, metakognisi adalah kemampuan untuk mengetahui apa yang kita ketahui dan apa yang tidak kita ketahui. Senada dengan itu, Flavell dalam Multadah (Masni, 2015) juga mengemukakan bahwa metakognisi adalah kesadaran seseorang tentang bagaimana ia belajar, bagaimana ia menilai suatu kesukaran dalam masalah, bagaimana ia mengamati tingkat pemahaman dirinya, bagaimana ia menggunakan berbagai informasi yang dimilikinya untuk mencapai tujuan serta bagaimana ia menilai kemajuan belajarnya.

Pendekatan metakognitif memiliki ciri utama yaitu dosen menyadarkan kemampuan metakognitif mahasiswa dengan mengajukan pertanyaan-pertanyaan metakognitif berisi pemahaman masalah, perencanaan penyelesaian masalah dan meriview hasil penyelesaian masalah (Nindiasari, 2013). Pertanyaan metakognitif adalah pertanyaan-pertanyaan yang di dalamnya terdapat tiga jenis pertanyaan yaitu pertanyaan pemahaman, pertanyaan koneksi dan pertanyaan strategi (Krisna, dkk dalam Masni, 2015). Dengan pengajuan pertanyaan metakognitif, mahasiswa akan mampu memantau proses kemampuan berpikirnya sehingga secara tidak langsung mahasiswa telah mampu mengembangkan pengaturan diri (self regulation).

\subsection{Pendekatan Metakognisi dalam Pembelajaran Matematika}

Dalam pembelajaran matematika, tipe pengetahuan kognitif yang berhubungan dengan pemecahan masalah matematika dapat diuraikan sebagai berikut (Garofalo dan Lester dalam Murni, 2013) : 1. Pengetahuan individual berupa penilaian seseorang tentang potensi dan keterbatasannya di bidang matematika 2. Pengetahuan tugas berupa keyakinan seseorang tentang materi matematika sebaik keyakinannya pada sifat dari tugas matematika 3. Pengetahuan strategi matematika mencakup kesadaran seseorang terhadap strategi yang membantu untuk memahami masalah, mengorganisasi informasi, merencanakan solusi, mengeksekusi rencana dan mengecek hasil, meliputi pengetahuan algoritma dan heurstik.

Pendekatan metakognitif dalam pembelajaran matematika dapat dilaksanakan dengan berbagai cara, selama

\section{Pengaruh Pendekatan Metakognisi Terhadap Kemampuan Pemecahan Masalah Matematika Mahasiswa Mesin Dan Peralatan Pertanian Politeknik Gorontalo}


yang menjadi inti pembelajarannya adalah untuk mengevaluasi metakognisi siswa melalui pemberianpemberian pertanyaan-pertanyaan metakognitif. Salah satu cara yang diusulkan oleh penulis adalah dengan menggunakan kartu metakognisi, yang berisi pertanyaan-pertanyaan metakognitif yang dapat disesuaikan dan disusun berdasarkan topik atau materi yang sedang dipelajari di kelas (Fior, 2015).

\section{HASIL DAN PEMBAHASAN}

Berdasarkan hasil evaluasi penelitian diperoleh bahwa penggunaan pendekatan metakognisi dapat meningkatkan kemampuan pemecahan masalah matematika mahasiswa pada mata kuliah matematika teknik. Oleh karena itu, pendekatan ini dianggap layak untuk digunakan dalam pembelajaran matematika, khususnya pada mataeri-materi yang relevan sebagaimana halnya materi penelitian ini.

Namun demikian, dalam proses perkuliahan dengan menggunakan pendekatan metakognisi ini memungkinkan adanya mahasiswa yang pasif dalam kelompoknya. Oleh karena itu, dosen selalu memantau semua kelompok untuk memastikan semua mahasiswa aktif dalam kelompoknya.

Indikasi lain yang dapat diamati adalah pemahaman konsep mahasiswa. Dari hasil yang telah diperoleh, dapat disimpulkan bahwa pendekatan metakognisi dapat meningkatkan kemampuan pemecahan masalah matematika mahasiswa. Salah satu faktor yang menyebabkan terjadinya peningkatan adalah keaktifan mahasiswa dalam kegiatan perkuliahan.

\section{KESIMPULAN}

Berdasarkan hasil penelitian dan pembahasan maka dapat diambil ksimpulan sebagai berikut :

1. Terdapat peningkatan kemampuan pemecahan masalah matematika mahasiswa yang diajarkan menggunakan pendekatan metakognisi,

2. Perbedaan ini ditunjukkan berupa skor rata-rata hasil belajar mahasiswa yang diajarkan dengan menggunakan pendekatan metakognisi lebih tinggi dibanddingkan dengan skor rata-rata hasil belajar mahasiswa yang diajarkan secara konvensional.

\section{DAFTAR PUSTAKA}

Costa, A. (Ed). (2000) Developing Minds: A Resource Book of Teaching Thinking. Alexandria, VA: ASDC

Fior, Norina Megan. (2015). Investigating and Foresting Metacognition in Early Math Learners. Doctoral Thesis of University of Calgary.

Kurniawan, Rudi., 2010, Pemahaman dan Pemecahan Masalah Matematis (Artikel Kajian Pendidikan Matematika. Makalah disampaikan pada Seminar Nasional Matematika dan Pendidikan Matematika di UNY pada tanggal 27
November 2010.

Masni, Dwika. (2015). Pendekatan Pembelajaran Metakognitif Advance Organizer dan Scientific Discovery Untuk Meningkatkan Kemampuan Pemecahan Masalah Matematika dan Kebiasaan Berpikir Matematik Siswa Kelas VIII. Tesis UPI. Tidak Diterbitkan.

NCTM, 2000, Principles and Standards for School Mathematics. Reston, Virginia: National Council of Teachers of Mathematics. (Online). http://www.netm.org/.

Nindiasari, Hepsi (2013) Meningkatkan Kemampuan Dan Disposisi Berpikir Reflektif Matematis Serta Kemadirian Belajar Siswa SMA Melalui Pembelajaran Dengan Pendekatan Metakognitif. Disertasi UPI. Tidak Diterbitkan

Polya, G (1985). How to Solve It. A New Aspect of Mathematical Method $\left(2^{\text {nd }}\right.$ ed). Princeton, New Jersey : Princeton University Press.

Ruseffendi,E.T (1991b). Penilaian Pendidikan dan Hasil Belajar Siswa Khususnya dalam Pengajaran Matematika untuk Guru dan Calon Guru. Bandung: Tidak diterbitkan.

Sanjaya, Wina. (2008). Perencanaan dan desain sistem pembelajaran. Jakarta: Kencana Prenada Media Group.

Sujono (1988). Pengajaran Matematika untuk Sekolah Menengah. Jakarta: Proyek Pengembangan LPTK, Depdikbud

Sumarmo,U, Dedy, E dan Rahmat (1994). Suatu Alternatif Pengajaran untuk MeningkatkanPemecahan Masalah Matematika pada Guru dan Siswa SMA. Laporan Hasil Penelitian FPMIPA IKIP Bandung

\section{Pengaruh Pendekatan Metakognisi Terhadap Kemampuan Pemecahan Masalah Matematika Mahasiswa Mesin Dan Peralatan Pertanian Politeknik Gorontalo}

